\title{
REWRITING THE WESTERN: TRANSNATIONAL DIMENSIONS AND GENDER FLUIDITY IN SEBASTIAN BARRY'S DAYS WITHOUT END
}

\author{
REESCRIBIENDO EL WESTERN: DIMENSIONES \\ TRANSNACIONALES Y FLUIDEZ DE GÉNERO EN \\ DAYS WITHOUT END, DE SEBASTIAN BARRY
}

\author{
DAVID RÍO RAIGADAS \\ Universidad del País Vasco/ Euskal Herriko Unibertsitatea \\ david.rio@ehu.eus
}

\begin{abstract}
The present essay will explore the Irish writer Sebastian Barry's transnational rendering of the American West in his novel Days without End (2016), emphasizing his representation of neglected western questions and realities and his revision of traditional western tropes and archetypes. Barry's approach to the American West in Days without End moves beyond the regional and national imagery of this territory, revealing its international and hybrid properties and its multiple and overlapping cultures. It is argued that Barry's recreation of a different reality from the traditional western monomyth of masculinity, individualism, and AngloAmerican conquest allows him to challenge classical frontier narratives and to address international and transcultural issues, such as gender fluidity. The novel, whose main protagonist and narrator is a poor, homosexual Irish immigrant, embraces a different West, questioning romanticized versions of the westward expansion and drawing interesting connections between the Irish immigrants in this region and the Native Americans. Overall, Days without End may be viewed as an acute depiction of the transnational dimension of the American West, proving the power of the Western to overcome its traditional formulaic and mythic boundaries and to travel across global spaces.
\end{abstract}

Keywords: American West, Sebastian Barry, transnational, frontier mythology, revisionism, gender. 


\section{Resumen}

El presente artículo explora la lectura transnacional que el autor irlandés Sebastian Barry realiza del Oeste norteamericano en su novela Days without End (2016), haciendo hincapié en su representación de temas y realidades del Oeste tradicionalmente relegados al olvido y en su revisión de los tropos y arquetipos del "western". A la hora de retratar el Oeste en Days without End, Barry va más allá del imaginario regional y nacional de este territorio, mostrando sus características internacionales e híbridas y sus culturas múltiples y superpuestas. Se argumenta que la recreación de Barry de una realidad diferente al tradicional monomito "western" de masculinidad, individualismo y conquista anglo-americana, le permite cuestionar las narraciones clásicas de la frontera y abordar asuntos internacionales y transculturales, como la fluidez de género. La novela, cuyo principal protagonista y narrador es un irlandés pobre y homosexual, muestra un Oeste diferente, poniendo en cuestión las versiones románticas de la expansión hacia el Oeste y trazando interesantes conexiones entre los inmigrantes irlandeses en esta región y los nativo-americanos. En conjunto, Days without End puede considerarse como un retrato agudo de la dimensión transnacional del Oeste americano, mostrando el poder del "western" para superar los tradicionales límites del mito y del género o fórmula y viajar a través de espacios globales.

Palabras clave: oeste americano, Sebastian Barry, transnacional, mitología de la frontera, revisionismo, género.

\section{Introduction: Transnationalism in the American West and Barry's Revision of Frontier Mythology}

The expansion of transnationalism in literary and cultural studies has certainly contributed to the increasing consolidation of critical perspectives focused on the global dimension of certain regions whose cultural iconography has achieved a powerful impact on an international audience. Such is the case of the American West, which was often built upon a history of cultural transfers, multinational features, and global flows. As Janne Lahti has claimed, the "West was international before it became national, and it became known and placed in a global context of empires, markets, epidemics, and knowledge before it was claimed by the United States and its brand of settler colonialism" (2019: 17). Similarly, Rio and Conway have argued that the "transnational dimension of the West is already present in the origins of a territory with borders and boundaries characterized by violence, cultural exchange, transculturation and heterogeneity" (2019: x). The imagery of the American West has traveled across national borders, challenging traditional 


\section{Rewriting the Western}

reductionist interpretations of western stories and films as quintessential 'American' cultural products and revealing the transnational implications of the western experience. For example, Cynthia J. Miller and A. Bowdoin Van Riper have stated that the international appeal of western films may be explained in part by "the potential for historical experiences of one culture to resonate with the audiences of another" (2014: xiv). Contemporary approaches to the American West and the Western are increasingly embracing a postregional dimension or postwestern perspective that emphasizes the dynamic and transnational ingredients of western motifs and themes. As Susan Kollin has claimed, "postwestern studies work against a narrowly conceived regionalism, one that restricts western cultures of the past and present to some predetermined entity with static borders and boundaries" (2007: 11). In fact, the case for transnationalism in western American studies has been promoted by a growing number of scholars in the last few decades. This is the case of Neil Campbell, who has pointed out that "to examine the American West in the twenty-first century is to think of it as always already transnational, a more routed and complex rendition, a traveling concept whose meanings move between cultures, crossing, bridging, and intruding simultaneously" (2008: 4). Similarly, Steven Frye has argued that "this remapping of the West, which preserves but enriches the regional and geographic model with concepts of movement that can be charted along ethnic, economic, and cultural lines, has led to a more complete understanding of the American West as a locus point for an international imaginary" (2016: 3-4).

A transnational perspective seems particularly appropriate when approaching Sebastian Barry's Days without End (2016), a story that shows how the conventions and tropes of the Western can be rewritten to account for otherness, transculturation, globalization, and the revision of frontier mythology. Barry locates the American West in a transnational context, linking western tropes and Irish historical and contemporary issues and deconstructing notions of exceptionalism related to the frontier experience as a quintessential American phenomenon. Days without End is the seventh novel by this acclaimed Irish writer and the fourth one dealing with a member of the McNulty clan. With this novel, Barry was awarded for the second time the prestigious Costa Book of the Year Prize. Its main protagonist and narrator, Thomas McNulty, is an Irish immigrant who flees to America as a thirteen-year-old orphan to escape the Great Famine, participating in the Indian Wars and in the Civil War. The novel opens with McNulty recounting his experiences as a seventeen-year soldier in Missouri in 1851. This character, according to Barry himself, grew out of a reference his grandfather once made to a past relative who fought in the Indian Wars ("An Irish Immigrant"). Although Barry's novel is mostly set in the Old West, this narrative departs from traditional cowboy mythology and romanticized versions of the conquest and exploration of 


\section{David Río Raigadas}

this territory. In fact, Days without End challenges archetypal frontier mythology, complicating classical constructions of the American West and opening iconic western tropes up to transnational reconceptualization. It is a novel where Barry, rather than perpetuating myths, interrogates them. He rejects the traditional western rhetoric of conquest, masculinity, individualism, and Anglo-Saxon power to focus instead on neglected stories and identities in the western imaginary. As Neil Campbell has stated, "The novel imagines and performs the West and America differently" (2018: 232, emphasis in original).

Despite its frontier setting and its immigrant protagonist, Days without End cannot be regarded as a conventional novel about immigrants in the Old West who believe in the dream of westward hope and its mythology of plenty and promise. Certainly, as Jeffrey Wallmann has put it, "the cultural mythology underlying westerns is the American Dream, which for the most part derives from the myth of the New World" (1999: 17). However, Thomas McNulty, the protagonist of Barry's novel, is not depicted as an ordinary immigrant escaping from poverty in Europe and longing for economic success and self-realization in an open land where everything could begin afresh. Instead, McNulty represents an important departure from the West's expectations of masculinity, ethnocentrism, economic success, and individualism. In fact, he shares many traits of 'otherness' because he is a homosexual Irish immigrant who, together with his partner (John Cole), adopts a Sioux girl (Winona) in the American West of the mid-19th century, a heterosexual and racist territory.

In Days without End Barry connects Ireland and the American West, addressing the Irish role in the exploration and settlement of the frontier. Memories and traumas of fateful events in Ireland, in particular the Great Famine, are transferred and brought into the country of settlement. The relocation of past legacies and experiences to a new social, geographical, political, and cultural context leads to dynamic transfers and transnational affiliations that reshape monocultural approaches of classical frontier narratives. In the novel, McNulty's Irish origin introduces a series of issues that condition his experience as an immigrant in the American West. First of all, as a survivor of the Great Famine, McNulty is traumatized by hunger, whose lethal consequences he has suffered in his own family: "my sister and mother perished. They perished like stray cats, no one caring much. But the whole town was perishing" (2017: 29). In fact, on his way to America, he emphasizes the power of hunger to deprive individuals of their human features: "We were a plague. We were only rats of people. Hunger takes away what you are. Everything we were was just nothing then" (2017: 29). Hunger in the novel also acquires a transnational dimension because it is not limited to the Irish immigrants. Although Barry himself has noted that "as Irish people only reading 


\section{Rewriting the Western}

Irish history, sometimes we think we have the copyright on hunger" ("An Irish Immigrant"), he does not hesitate to portray in his novel the impact of hunger beyond Irish borders. Thus, the American West is not free from starvation, as illustrated by the Sioux, who are deprived of food by the federal government — "if they was waiting on government victuals they starved" (2017: 99). The recurrent images of starvation extend to McNulty's experiences in other parts of the United States, questioning the cultural mythology of the American Dream. Particularly haunting is the scene in a prisoner war camp in Andersonville (Georgia) during the Civil War where both Union captives and their guards are all starving: "They got precious little to eat theyselves so it's skeletons minding skeletons somewhat. They ain't withholding food, they ain't got any" (2017: 197).

In Barry's novel, the trauma of hunger coexists with recurrent images of dispossession, suffering, and death in the promised land. So, it may be argued that Days without End challenges the mythic rhetoric of America and the West, in particular as the land of opportunity, rejecting romanticized versions of this land for the Irish. The dream of westward hope and its mythology of plenty and promise is replaced in the novel by the emphasis on the fight for survival. In fact, Thomas McNulty, a survivor of the Great Famine, has to survive other traumatic experiences in America, such as the Indian Wars or the Civil War, and he has to reinvent himself against a context of painful ordeals where the Irish move from being victims of anti-Catholic bigotry and racism to becoming involved in the oppression of the Native Americans. The epic journey of McNulty and his partner across the American West allows Barry to illustrate the clash between frontier mythology and the reality of survival in this place, a region where the main characters are dehumanized by war, poverty, and racism. As Neil Campbell has stated, the novel portrays the West as "a brutal and unforgiving place of racial violence, genocide, gender inequality, and cruel disappointment" (2018: 238). The trope of the West as the land of new beginnings and regeneration is present in the novel, but it is reconceptualized by Barry, who cuts away foundational national frontier mythology. Significantly enough, in Barry's novel, Thomas McNulty, once in the United States (he had arrived there via Canada), goes from the West, Missouri and California, to the East, settling finally in Tennessee. This inversion of the traditional direction of the quest for the American Dream, the historical movement toward the West, can be regarded as a symbolical exposing of the artificiality of the myth of the American West.

Days without End reshapes a legacy of frontier writing inherited from authors such as James Fenimore Cooper, Owen Wister, or Zane Grey, deconstructing mythological archetypes and stories that evoke an overly romanticized era. In this sense, it is worth remembering that the mythologized representation of the 


\section{David Río Raigadas}

West is a transcultural phenomenon, appropriated by multiple narratives beyond the US borders. In fact, Barry's novel undermines the vision of the American West as a place of romance and adventure popularized, for example, by earlier Irish authors, such as James McHenry, Dillon O'Brien, or George Jessop, and, in particular, by Thomas Mayne Reid, whose Wild West antirealistic fiction transcended national canons, illustrating the power of western mythology and imagery to travel beyond the Atlantic. Despite the obvious differences between Reid's best-known western novel, The Headless Horseman (1866), and Barry's Days without End, both narratives share a relocation process of legacies of the Irish past to the frontier setting. Thus, whereas Reid's novel inserts Irish folklore and myth into a romanticized portrait of the West (Naughton and Naughton 2013: 148), Barry's approach to the frontier is permeated by elements of Irish history and culture that interact powerfully with western imagery, contributing to reconfiguring classic tropes and to a transcultural dialogue about the Irish immigrant experience of the American West.

\section{Victims and Victimizers of Settler Colonialism}

Days without End focuses on the army experiences of Thomas McNulty, depicting the army basically as the only way out from famine for the Irish immigrants: "The only pay worse than the worst pay in America was army pay. And they fed you queer stuff till your shit just stank. But you were glad to get work because if you didn't work for the few dollars in America you hungered. Well, I was sick of hungering" (2017: 2). Enlisting in the army at that time often meant a deeply distressing trial for Irish immigrants like $\mathrm{McNulty}$ because it involved participating in traumatic events such as the Indian Wars or the Civil War. As Camila Franco Batista has argued (2017: 103), we may talk about the intertwining in the novel of two traumatic experiences, the Great Famine and war in America. The army also often meant a way for the Irish to earn citizenship, a strategy to counter the social and cultural discrimination they encountered in the United States, illustrated by "Irish not need to apply" postings. As Peter O'Neill has argued, "the combination of Catholic religion, Irish ethnicity, utter poverty, and massive numbers" made the "Famine Irish" regarded as "a threat to the racial hierarchy of the United States during the mid-nineteenth century" (2017: 2). According to historical records, about 42 percent of the new army recruits in 1850-51 were Irish, and of 183,659 soldiers who enlisted in the army after the Civil War, 38,659 had been born in Ireland (Dungan 1993: 42). As soldiers, the Irish took part in the conquest of the West, becoming instruments of a painful process of colonization and destruction. Barry himself has talked about the "historical 


\section{Rewriting the Western}

sorrow of an Irish person, himself essentially a native person, an aboriginal person, by a great trauma having to go to America, joining an Army that was engaged in the destruction, erasure and removal of a people, the Native American people, not unlike himself" ("An Irish Immigrant"). Several scholars have also emphasized the problematic and complex relationship between the Irish soldiers and the Native Americans during the westward expansion. Marguerite QuintelliNeary, for example, has talked about a "curious, schizophrenic blurring of racial boundaries", with Irish soldiers in the Indian Wars making "their warrior status known as they marched into battle to the sounds of Irish music... while, at the same time, many of them established a bond with the very same Native Americans, intermarrying with them" (2004: 47-48). Barry's novel does not only limit to reveal the contradictions of the Irish involvement in the extermination of the original inhabitants of the West, but it also exposes the tragic irony of their role during the American Civil War. About 200,000 Irish soldiers fought in this war, most of them (about 150,000) enlisted in the Union army (Rodgers 2008). Barry's novel highlights the inner incongruity of the Irish involvement in this war, a conflict where there are Irish-American companies on both sides calling out the same battle cries and fighting against each other: "The Irish Rebs are shouting too, shouting filthy things in Gaelic. Then we reach each other and it is all wrestling, punching, and stabbing" (2017: 173). The land of opportunity for these immigrants, with a common traumatic past of hunger and dispossession, becomes the site of a fratricidal fight where ethnic bonds are sacrificed in the name of survival. In general, in its approach to Irish identity, Barry's novel rejects one-dimensional portraits, tending to integrate polarities, such as those represented by the Irish soldiers fighting for the Union and the Irish Rebs. In fact, ambivalence may be regarded as the dominant feature in Barry's portrayal of the Irish, with an emphasis on duality, contradiction, and ambiguity, as illustrated by the narrator's description of the archetypal Irishman: "He may be an angel in the clothes of a devil or a devil in the clothes of an angel but either way you're talking to two when you talk to one Irishman" (2017: 27). This ambiguity extends to different traits of the Irish character, as exemplified by McNulty's evaluation of the courage of the Irish soldiers: "An Irish trooper is the bravest man in the field and the most cowardly" (2017: 27).

Dichotomy, contradiction, and ambiguity are especially remarkable when Barry places his Irish characters in the Indian Wars. Certainly, the western genre, in general, contains a dualistic dimension because it is both an example of a narrative of settler colonialism, similar to other colonial narratives, and it is also a unique genre, linked to the peculiar US history of expansion and settlement. In the case of Barry's novel, this dichotomous condition becomes even more acute due to the particular interaction of the Irish immigrants with the native 


\section{David Río Raigadas}

inhabitants of the colonized American West. The novel certainly suggests an affinity between the Native Americans and the Irish based on the fact that both groups represent dispossession and dislocation. Both communities are victims of settler colonialism, and their common link is symbolically expressed in the novel by Thomas McNulty's choice of John Cole, a young man with Indian ancestors, as his partner in love and their adoption of a Sioux child. Barry himself has spoken about his personal identification with the Native Americans during his youth in Ireland: "when I was very young, I did, [...] like a lot of young people do, I made a strong connection between myself $[\ldots]$ and Native America. I grew my hair down to my waist when I was 19 at Trinity College the first chance I got. The only thing I ever played on the stage [...] I was cast as Tonto" ("An Irish Immigrant"). Both groups share common features of 'otherness' and oppression, as objects of an English colonial discourse that establishes their ethnical inferiority. As historian David Harding has noted, "as the English incursion into Ireland closely predates that of North American colonization, it can be seen as a dress rehearsal for the subjugation of Native Americans" (2005: 37). Marguerite Quintelli-Neary has alluded to the solidarity of a Native American tribe towards the Irish during the Famine: "the Choctaw tribe of Mississippi, which was forced to leave its ancestral home and undergo a forced march to Oklahoma in $1830,[\ldots]$ collected funds and sent relief money in the 1840 s to an unknown people who were starving on a remote island off Europe" (2004: 49). However, the empathy between the Irish immigrants and Native Americans, based on their common condition as an American underclass, was often more a theoretical assumption than a reality. The Irish were involved in the ethnic cleansing against the Native Americans in the West, moving from excluded to excluders in a process where racism and bigotry against a more vulnerable group often worked as an instrument to gain social and cultural acceptance in the New World. In fact, there are several historical examples of the unfair treatment of the Native Americans by Irish officers during the settlement process (Dungan 1993: 43-45). Similarly, Barry's novel portrays the Irish-American soldiers as perpetrators of brutal attacks against the Indians during the western colonization. Neil Campbell, for example, has used the term "uncanny kinship" (2018: 242) to refer to the relationship between both groups. Thomas McNulty and some of his Irish comrades in the army will participate in massacres against the Native Americans, leaving behind their historical role as victims to become victimizers. McNulty himself seems to be aware of the ironic implications of their active participation as instruments of colonization and extermination in the promised land when he juxtaposes their role in the American West with that of Oliver Cromwell's soldiers in Ireland in the $17^{\text {th }}$ century: "When that old ancient Cromwell come 


\section{Rewriting the Western}

to Ireland he said he would leave nothing alive. Said the Irish were vermin and devils. Clean out the country for good people to step into. Make a paradise. Now we make this American paradise I guess. Guess it be strange so many Irish boys doing this work" (2017: 263-264).

The novel underscores the soldiers" cruelty against the Native Americans: "It was just women and children all around us. Not a brave among them" (2017: 37). With this emphasis on the atrocities of the army, Barry departs from traditional frontier mythology to vindicate historical accuracy in the depiction of the expansion to the West. Barry is aware that the myth of the American West is often based on stereotypes and cultural representations where those who represent the 'Other', like the Native Americans, are deprived of their human features. Dehumanizing the 'Other', as David Sibley has claimed, "is one way of legitimating exploitation and exclusion from civilized society" (1995: 10). The profound ethnocentric bias of frontier mythology justifies the annihilation of the Native Americans in the name of progress and civilization, extending the trope of a 'savage war' to refer to the Indian Wars. Barry has acknowledged his use of historical sources to write about these wars, drawing connections with his research for a previous novel, A Long Long Way (2005), focused on the horror of World War I for the Irish troops: "I read for a year because, of course, you can't completely make it up. [...] And sometimes when I was reading, you know, I must confess that I lost heart. And I thought, I just can't. I can't actually do this. [...] It reminded me of when I was trying to write about the Irish soldiers in the First World War" ("An Irish Immigrant"). Barry was particularly influenced by the Sand Creek massacre in 1864, and he even admits that one of the characters, presumably Captain Silas Sowell, is based on an army officer who refused to participate in the massacre: "the terrible orders, and the terrible outcome, and the efforts of a man called Silas Soule - I tried to honor him by having him in the book with a different spelling" ("An Irish Immigrant"). The novel highlights not only the cruelty and inhumanity of the Indian Wars, but also their psychological impact on the main character, forced to admit the impact of evil on his own behavior: "I was affrighted and strangely affronted, but mostly at myself, because I knew I had taken strange pleasure from the attack" (2017: 37). The narrator realizes that their commitment to violence and brutality in the Indian Wars makes them face a sense of loss and an increasing dehumanization: "We didn't know where we were. We didn't for those moments know our own names. We were different then, we were other people. We were killers, like no other killers that had ever been. [...] We were dislocated, we were not there, now we were ghosts" (2017: 38-39). In this way, the colonization of the American West acquires a traumatic dimension not only for its victims but also for those who, like McNulty and his Irish comrades, 
participated in the extermination of the native population. We may even regard McNulty's narration of these cruel episodes as an attempt to expiate his own guilt by revisiting a traumatic past. As Camila Franco Batista has suggested, "he acknowledges that the war against the Indians had altered him and the other soldiers; they had ceased to be law men and became assassins" (2017: 109). In fact, the novel suggests that the border that separates the colonizer from the colonized is a contested and blurred line, questioning the traditional discourse of otherness in frontier mythology. To use Homi K. Bhabha's terms, we might even talk about the western frontier in Barry's novel as a place where "the place of difference and otherness, or the space of the adversarial [...] is never entirely on the outside or implacably oppositional" (1995: 32). In fact, the white soldiers who seem to represent progress and civilization are very close to the primitiveness and the savagery they are supposedly bound to eliminate.

\section{Neglected Gender Identities}

In Days without End, Barry also challenges traditional cowboy mythology, vindicating the existence of other neglected western identities. The main characters' national and personal identity, with its emphasis on class, sexual, and ethnic divergence, disputes the truth of reductionist interpretations of this territory and its cultural iconography. The novel blurs boundaries not only between cultures and ethnic groups, but also between genders, revising traditional representations of gender roles in western films and literature. Barry paints a vivid picture of the frontier where transgressive sexual and gender activities put into question popular understandings and memories about the masculine, heterosexual Old West. Thus, fixed gendered identities are disrupted from the beginning of the novel and gender fluidity related to its main male protagonists becomes particularly striking in a genre that, as Jane Tompkins has claimed, "worships the phallus" (1992: 28). Although several authors have argued about the "implicit homoeroticism of many Westerns throughout the history of the genre" (Piturro 2013: 117), classic western archetypes of the hero have traditionally emphasized a version of masculinity where there is an overemphasis on toughness, dominance, individuality, and physical strength. Barry's novel reveals the existence of alternative and complex definitions of masculinity in the American West, departing from archetypal views of male heroes related to mythical views of the West and individualistic male cultural models. Certainly, Thomas McNulty does not epitomize traditional masculine features in frontier mythology. It is not just that he develops a romantic relationship with John Cole and adopts a Sioux girl, but he also embodies an unfixed gender identity. In fact, the novel explores gender fluidity because, in 


\section{Rewriting the Western}

McNulty's case, his desire to dress as a woman and his maternal feelings for Winona coexist with his stereotypically masculine involvement in brutal war episodes: "I feel a woman more than I ever felt a man, though I were a fighting man most of my days" (273). Fixed gender identities are disrupted from the very beginning of the novel, as illustrated by the drag show where rugged miners, who seem to represent archetypal masculine myths of the West, are transformed into romantic men devoted to dancing with men disguised as women: "They need the illusion, only the illusion of the gentler sex" (2017:9). Through his cross-dressing with his lover John Cole for the miners of Daggsville (Missouri), the teenager Thomas becomes Thomasina: "Funny how as soon as we hove into those dresses everything changed. I never felt so contented in my life. All miseries and worries fled away. I was a new man now, a new girl. I was freed, like those slaves were freed in the coming war. I was ready for anything" (2017: 11). In fact, cross-dressing was not uncommon in the Old West, practiced either for practical reasons or to express non-conformism with one's assigned gender identity. As historian Peter Boag has noted, "cross-dressers were not simply ubiquitous, but were much a part of daily life of the frontier and in the West" (2011: 1-2). The issue of cross-dressing serves Barry to explore unconventional understandings of masculinity, homosexual love, and gender roles in the Old West. Once again, he questions frontier mythology, vindicating alternative ways of loving "in a world defined by masculine pursuits and western myth" (Campbell 2018: 245). Certainly, it is possible to draw connections between Barry's examination of queer lives in the American West and Annie Proulx's well-known story "Brokeback Mountain". Both stories revise the hyper-masculine and hyper-heterosexual classic version of the American West, a view that has prevailed in the popular imagination even in contemporary times. Even the success of the movie version of "Brokeback Mountain" in 2005 could not avoid that "popular audiences [...] simply found it incongruous and therefore uproariously laughable that homosexuality could exist within what was popularly understood to be the classic West - not just as a place but as a culture represented by the iconic cowboy" (Boag 2011: 2). Barry's novel focuses on a time, the mid$19^{\text {th }}$ century, in which, with the scarce presence of women, "the always unstable line dividing the homosocial from the homosexual - that is, dividing non-sexual male bonding activities from sexual contact between men- became even more blurred" ("Paradise of Bachelors"). The frontier provided its pioneers with an opportunity for reinvention, including the transgression of clear-cut gender norms and a fluidity of identity that challenged apparently stable binaries. In fact, Thomas McNulty and John Cole's love affair cannot be regarded strictly as an anomaly in the context of the western expansion. As stated in the article "Paradise of Bachelors", "as traditional notions of 'normal' gender roles were challenged and unsettled, men could display both subtly and openly the erotic connections they 


\section{David Río Raigadas}

felt for other men". This article even includes an explicit reference to men's dances for their fellow miners: "When the miners at Angel Camp in southern California held dances, half of the men danced the part of women, wearing patches over the crotches of their pants to signal their 'feminine' role". And Barry himself has explained that he did research on this topic because he was powerfully attracted by the idea of men occupying "not only public spaces usually occupied by women, but also domestic spaces" ("An Irish Immigrant").

Barry's exploration of homosexual love in the American West may be regarded as a significant example of the potential of the Western to travel beyond time and space, addressing transnational issues and bringing to light questions and realities that go far beyond the traditional limits of American exceptionalism and frontier mythology. Barry has explained that his decision to write a novel focused on two gay men participating in the conquest of the West is connected to both personal reasons and political issues. Thus, the novel is dedicated to his son, Toby. As Barry himself stated in an interview with Stephen Moss in The Irish Times in 2017, his son's coming out as gay inspired him to write this book: "His unhappiness fell away, my unhappiness fell away, and from that moment on we entered into this extraordinary period where he was instructing me in the magic of gay life". But the genesis of the novel extends beyond the personal dimension because it is also related to a political and social question that polarized public opinion in Ireland at the beginning of the present century: the issue of same-sex marriage. Ireland, a country where same-sex sexual activity was not decriminalized until 1993, became twenty-two years later the first country to legalize same-sex marriage by popular vote, emerging as one of the most progressive nations in terms of gay rights. In May 2015, over 60 percent of Irish voters approved the addition of the following seventeen words to their constitution: "Marriage may be contracted in accordance with law by two persons without distinction as to their sex". Barry had an active role in the campaign for marriage equality. He wrote an open letter to the readers of The Irish Times on May 12,2015, where, firstly, he based his support of marriage equality on personal reasons, defining himself as "the more than proud father of one shining person who happens to be a member of the LGBT community". In this letter, he also rejected the idea of tolerance being the main reason to allow all citizens in Ireland to marry regardless of their gender. Instead, he justified his support for marriage equality as a way to apologize for "all the hatred, violence, suspicion, patronisation, ignorance, murder, maiming, hunting, intimidation, terrorising, shaming, diminishment, discrimination, destruction, and yes, intolerance, visited upon a section of humanity for God knows how many hundreds of years, if not millennia" ("Marriage Referendum"). Certainly, the influence of contemporary issues that trespass regional, national, and mythical boundaries — such as the Irish same-sex marriage question - on the contents of 


\section{Rewriting the Western}

Barry's novel reveals the capacity of the Western to resonate with writers and readers from around the world. In fact, Days without End is a Western that shows the malleability of frontier mythology and the potential of this genre to promote significant examination of transcultural and global experiences. As Luke Gibbons has stated, "it is no longer possible to sequester questions of class, race and gender within conventional national boundaries, Irish, American or otherwise. If the Atlantic is a frontier, it traverses time as well as space, as if oceans have memories of their own" (2004: 47).

\section{Beyond Individualism}

In Barry's novel, the love relationship between Thomas McNulty and John Cole challenges not only archetypal masculine models in frontier mythology, but also classical mythical views of the West emphasizing individualism as a dominant cultural feature. Since Frederick Jackson Turner emphasized the role of the frontier as "productive of individualism" (1894:221) in his well-known "frontier thesis", the connection between the westward expansion, American character, and individualism became a 'cliché' in American popular culture. This 'rugged individualism', to use the term coined by President Herbert Hoover, as a quintessential part of the frontier experience and the basis of American society has been put into question by revisionist approaches to the history of the West that have brought attention to the communal attitudes and behavior of the settlers. In fact, as John Mack Faragher has noted, "many nineteenth-century observers of the 'Old West' saw more evidence of community than did Turner" (1986: 130). In Days without End, we may observe Barry's departure from the stereotypical rugged individualism of frontier mythology to focus on the main couple's attraction and loyalty to each other. Thomas McNulty and John Cole do not embody the classical figure of the lonely independent cowboy that is so prominent in many Westerns. As Shai Biderman has stated, "this characteristic of loneliness is not a random feature of the western hero; rather, it's the hero's trademark" (2010: 14). However, early in Barry's novel it is stated that "two is better together" (2017: 4), and the two main characters will remain together and treasure their clandestine love even if they have to cope with several traumatic and violent experiences, such as the Indian Wars or the Civil War. Their time in the army symbolizes another powerful example of the important role of community bonds in this novel. Their volunteering for the army seems to challenge the main ideas defended by Turner about the anti-social condition of the frontier, a place that "produces antipathy to control, and particularly to any direct control" (1894: 222). Thomas McNulty and John Cole are willing to 


\section{David Río Raigadas}

accept control and limits to their personal freedom in exchange for a job that basically means for them a way out from famine. The army works as an institution where individual egos are sacrificed in favor of the well-being of the group, in this case, a country immersed in internal violent feuds. Barry's novel does not present the army as a community based on close cooperation and mutual help, but rather as an organization where discipline is the major rule, as illustrated by the court martial of Trooper Pearl, "though the officers presiding had no real notion of what his offence might have been" (2017: 63). In fact, the main protagonists' voluntary enlistment in military service soon becomes a compulsory engagement for a period of duty in which there is no place for dissenters: "we sure getting poorer and uglier in the army but better than be shot" (2017: 63). After the end of their first term of service in the army, community life is still a reference for John Cole and Thomas McNulty because, after their adoption of Winona - "a daughter not a daughter but who I mother best I can" (2017: 236) - they try to live like a family. Turner himself in his "frontier thesis" had claimed that the family was the basic form of organization during the westward expansion: "complex society is precipitated by the wilderness into a kind of primitive organization based on the family" (1894: 221). However, in Barry's novel, the main protagonists' family is far from being the conventional frontier family and some reviewers have even viewed this family as anachronistic and hard to credit (see, for example, Clark 2016). Certainly, the members of this family disrupt traditional gender roles and ethnic and sexual boundaries. Besides, their lives are interconnected to those of other members of the rural community where they temporarily settle, including an Irish friend and freed slaves. As Neil Campbell has suggested, Barry portrays "an alternative community or muintir in Gaelic" (2018: 246, emphasis in original), in which there is a sense of cooperation that clashes with the traditional frontier emphasis on individualism. For Campbell, this alternative community would share certain similarities with the Irish agricultural system of rundale, a traditional form of occupation of land that "set the Irish apart from the self-consciously individualistic and independent western American farmer" (Emmons 2010: 110). This alternative community will represent only an interlude in Thomas and John's hazardous lives because, in the second part of the novel, the army recovers its privileged position as their reference community. The military trial of Thomas, first accused of being a deserter and later of killing an officer to save Winona's life, symbolizes the power of a closed institution to undermine the freedom and individuality of those subject to its discipline. In the end, Thomas's survival depends on the will of other members of the military community, as illustrated by Major Neale's final deposition and his intercession for his life. Interdependence, even in such a hierarchical community as the army, becomes once again a key feature for the 


\section{Rewriting the Western}

fate of the main characters. The end of the novel also hints that McNulty will choose a future life in a community, recovering the alternative family he had managed to build with John Cole and Winona after his first term in the army. In fact, Barry's most recent novel, A Thousand Moons, published in March 2020, is a sequel to Days without End, but this time the setting is not the Old West, but Tennessee, where the three main characters settle to live like a family, and Thomas McNulty is replaced in the narrator's role by Winona.

\section{Conclusion}

Days without End provides the reader with an insightful transnational reading of the American West, complicating traditional constructions of a genre usually identified with a series of national myths and tropes. Barry's revision of archetypal frontier mythology allows him to explore neglected western experiences in which 'otherness', transgression, and divergence play a pivotal role. His novel is concerned with international political and cultural questions and realities, and vindicates a shift toward a post-regional and post-national dimension for a proper representation of frontier stories, downplaying the conventional western rhetoric of conquest, masculinity, individualism, and Manifest Destiny. Barry presents us with a narrative that challenges the Anglo-American mainstream idea of progress and success in the West, subverting stereotypes and addressing problematic intercultural and transnational exchanges. His novel enables a revision of the traditional imagery of the Western, emphasizing the extension of cultural transfers and global flows in western narratives. The book contributes to a cross-cultural dialogue about the multiple meanings of the American West, both with its insightful representation of the Irishness trope in the frontier days and with its use of contemporary Irish national and personal issues to conceive a western narrative. Overall, Days without End may be regarded as an illuminating approach to a complex, transcultural, and unconventional American West and as a novel that proves the power of the Western to move beyond its mythic, nationalistic, and formulaic frameworks and to travel across global spaces. ${ }^{1}$

\section{Notes}

1. I am indebted to the Spanish Ministry of Education, Culture, and Sports (PGC2018-094659-B-C21), FEDER, and the
Basque Government (IT 1026-16) for funding the research carried out for this essay. 


\section{Works Cited}

"An Irish Immigrant Fights on the Great Plains in Days without End". 2017. NPR (February 20). <https://www.npr.org/2017/02/20/515806702/anirish-immigrant-fights-on-the-gre1at-plains-indays-without-end? $\mathrm{t}=1581414598138>$. Accessed January 15, 2020.

BArry, Sebastian. 2005. A Long Long Way. New York: Viking.

BARRY, Sebastian. (2016) 2017. Days without End. London: Faber and Faber.

Barry, Sebastian. 2020. A Thousand Moons. London: Faber and Faber.

Batista, Camila Franco. 2017. "Soldiers and Indians: Victim and Perpetrator Traumas in Sebastian Barry's Days without End". Em Tese 23 (3): 100-112.

BhABHA, Homi K. 1995. "Signs Taken for Wonders". In Ashcroft, Bill, Gareth Griffiths and Helen Tiffin (eds.) The Post-Colonial Studies Reader. New York: Routledge: 29-35.

Biderman, Shai. 2010. "'Do Not Forsake Me, Oh, My Darling': Loneliness and Solitude in Westerns". In McMahon, Jennifer L. and B. Steve Csaki (eds.) The Philosophy of the Western. Lexington: University Press of Kentucky: 13-29.

BOAG, Peter. 2011. Re-Dressing America's Frontier Past. Berkeley: University of California Press.

CAmpbell, Neil. 2008. The Rhizomatic West: Representing the American West in a Transnational, Global, Media Age. Lincoln: University of Nebraska Press.

CAmpbell, Neil. 2018. "'The Seam of Something Else Unnamed': Sebastian Barry's Days without End". Western American Literature 53 (2): 231-252.

Clark, Alex. 2016. "Days without End by Sebastian Barry Review - a Bravura Journey into America's Past". The Guardian (October 28). <https://www.theguardian.com/books/2016/ oct/28/days-without-end-by-sebastian-barryreview>. Accessed January 9, 2020.
Dungan, Myles. 1993. Distant Drums; Irish Soldiers in Foreign Armies. Belfast: Appletree Press.

Emmons, David M. 2010. Beyond the American Pale:The Irish in the West, 1845-1910. Norman: University of Oklahoma Press.

FARAgheR, John Mack. 1986. Sugar Creek: Life on the IIlinois Prairie. New Haven:Yale U.P.

FrYE, Steven. 2016. "Introduction". In Frye, Steven (ed.) The Cambridge Companion to the Literature of the American West. New York: Cambridge U.P.: 1-6.

GibBons, Luke. 2004. "Ireland, America and Gothic Memory: Transatlantic Terror in the Early Republic". Boundary 231 (1): 25-47.

HARDING, David. 2005. “Objects of English Colonial Discourse: The Irish and Native Americans". Nordic Irish Studies 4: 37-60.

Kollin, Susan. 2007. "Introduction: Postwestern Studies, Dead or Alive". In Kollin, Susan (ed.) Postwestern Cultures: Literature, Theory, Space. Lincoln: University of Nebraska Press: ix-xix.

LAHTI, Janne. 2019. The American West and the World: Transnational and Comparative Perspectives. New York: Routledge.

“Marriage Referendum”. 2015. The Irish Times (May 12).<https://www.irishtimes.com/opinion/ letters/marriage-referendum-1.2208406>. Accessed January 8, 2020.

MILleR, Cynthia J. and Bowdoin VAN RIPER. 2014. "Introduction". In Miller, Cyncia J. and Bowdoin Van Riper (eds.) International Westerns: Re-Locating the Frontier. Lanham: The Scarecrow P. Inc.: xi-xxviii.

Moss, Stephen. 2017. "Sebastian Barry: 'My Son Instructed me in the Magic of Gay Life'". The Irish Times (Feb. 2). <https://www. irishtimes.com/culture/books/sebastianbarry-my-son-instructed-me-in-the-magic-ofgay-life-1.2960757>. Accessed January 7, 2020. 


\section{Rewriting the Western}

Naughton, Yulia Pushkarevskaya and Gerald David NAUGHTON. 2013. "'Westward Went I in Search of Romance': The Transnational Reception of Thomas Mayne Reid's Western Novels". CEA Critic 75 (2): 142-157.

O'NeILL, Peter D. 2017. Famine Irish and the American Racial State. New York: Routledge.

"Paradise of Bachelors: The Social World of Men in Nineteenth-Century America". 2003. In American Passages: A Literary Survey (Annenberg Learner). Oregon Public Broadcasting. <https://www.learner. org/series/ american-passages-a-literarysurvey/masculine-heroes/activities/>. Accessed January 10, 2020.

Piturro, Vincent. 2013. “Reverse Transvestism and the Classical Hero: The Ballad of Little Jo and the Archetypal Western (Fe)male". In Matheson, Sue (ed.) Love in Western Film and Television: Lonely Hearts and Happy Trails. New York: Palgrave Macmillan: 111-124.

Proulx, Annie. 1997. "Brokeback Mountain". The New Yorker (October 13): 74-85.

Quintelli-Neary, Marguerite. 2004. “Establishing Boundaries in the Irish American West". Études Irlandaises 29 (2): 43-57.
REID, Mayne. 1866. The Headless Horseman: A Strange Tale ofTexas. London: Richard Bentley.

RıO, David and Christopher Conway. 2019. "Introduction: The Case for Transnationalism in the American Literary West". In Rio, David and Christopher Conway (eds.) Writing the Global Western: Circulations and Transformations of the American West in World Literature. Special issue of Western American Literature 54 (2): ix-xiv.

Rodgers, Thomas G. 2008. Irish-American Units in the Civil War. New York: Bloomsbury.

Sibley, David. 1995. Geographies of Exclusion: Society and Difference in the West. New York: Routledge.

Tompkins, Jane. 1992. West of Everything: The Inner Life of Westerns. New York: Oxford U.P.

TURNER, Frederick Jackson. 1894. "The Significance of the Frontier in American History". In Annual Report of the American Historical Association for the Year 1893. Washington D.C.: Government Printing Office: 199-227.

Wallmann, Jeffrey. 1999. The Western: Parables of the American Dream. Lubbock: TexasTech U.P. 